\title{
ESTIMATION OF THE CONSUMPTION OF MEDICINAL SUBSTANCES IN THE NEW MARINE FISH FARMING IN FRANCE.
}

\author{
ESTIMATION DE LA CONSOMMATION FRANÇAISE DE SUBSTANCES \\ MÉDICAMENTEUSES EN PISCICULTURE MARINE NOUVELLE.
}

\author{
J.C. RAYMOND (1) et G. BLANC (2)
}

(1) SAVU-CNPMEM, 81 rue Berthe Morisot, 34430 Saint-Jean de Vedas, France.

(2) Unité associée INRA de Chimiothérapie Aquacole et Environnement, Ecole Nationale Vétérinaire de Nantes, Atlanpole-La Chantrerie, BP 40706, Nantes Cedex 03, France.

In the global context of the environmental impact of human activities related to animal production, the quantitative effect of aquaculture has certainly a very low level (PILLAY, 1997). Nevertheless, as in many agricultural activities, the environmental impact of aquacultural productions using biologically active chemical substances, whose use is strictly controlled (BLANC et al., 1998) and performed under the responsibility of capable prescribers, still remains poorly understood.

Thus today, in the complex and sometimes conflictual situation where decisions are made relative to the management of national resources, it seems necessary to perform a risk / benefit analysis in order to develop sustainable ecological activities. An initial step in this analysis requires the description of the utilization of chemotherapeutic compounds which could ultimately affect the marine ecosystems.

Drugs used in fish farming, like all veterinary medicines in France, are regulated by the European and national drug legislations. This implies that all medicinal veterinary products, including also the medicated feed delivered by feed-mills, used in cultured fish have to be prescribed by veterinarians. In France, the safety of fish farmed products is assessed by the national laboratories involved in regularly performing random spot checks to survey chemotherapeutic residues under national food inspection and quality control programmes. Additionally, in other countries, such as Norway, national surveillance programme for drug prescribing in farmed fish has been added to the previous (BANGEN et al., 1994). This latter programme requires both the prescribing veterinarian and the dispensing pharmacy or feed-mill to send a copy of each prescription which is recorded in a computerized database.

In the absence of such a national surveillance programme for farmed fish in France, the aim of this study is to evaluate the national consumption of chemotherapeutants in the new fish farming, considering that the development of a sustainable aquaculture industry is bound to the control of its environmental impacts. In the present paper, the nature of the active compounds used in fish farming chemotherapy is specified in function of the main 
indication of marine fish farming. A theoretical estimation of the administered quantities of medicinal substances employed in marine fish farming is proposed.

In France, the prescription of veterinary drugs in marine fish farming is characterized by a low diversity, mainly because of regulation requirements (BLANC et al., 1998). Therefore, the therapeutic arsenal available in fish farming is exceptionally limited, and all diseases are not covered. Furthermore, in industrial farms, the decision to treat is made after analyzing the four following elements : (1) the prevalence of the disease, (2) the rate of instantaneous and cumulative mortality, (3) the diagnosis, and (4) the prognosis. This last point is essential in terms of profitability : a treatment is useful only if its cost is less than the predicted mortality without treatment, and especially the lives saved by the treatment. It is therefore not profitable to use a treatment when the predicted mortality is $<0.5 \%$, or when there is not an efficiently enough drug to reduce the cost of mortality of a value at least equal to the cost of the treatment. In this respect, the experience acquired regarding the evolution and the impact of different diseases in marine aquaculture is more limited than in other animal productions which benefit of longer insight. Therefore, one can conceive that latter productions could probably use less medicinal substances for equivalent pathologies.

\section{Table I}

Main curable diseases in marine fish farming.

\section{Tableau I}

Principales maladies curables en pisciculture marine.

\begin{tabular}{|c|c|c|c|c|}
\hline \multicolumn{2}{|c|}{ BACTERIOSIS } & \multicolumn{3}{c|}{ EXTERNAL PARASITOSIS } \\
\hline External & Septicaemic & Prolozoans & Monogeneans & Crustaceans \\
\hline $\begin{array}{c}\text { Flexibacteriosis from } \\
\text { Flexibacter martimus }\end{array}$ & $\begin{array}{c}\text { Vibriosis from } \\
\text { Vibrio anguillarum }\end{array}$ & Trichodina spp. & Diplectanum spp. & Lernanthropus spp. \\
\hline $\begin{array}{c}\text { Larval cutaneous gill } \\
\text { bacterlosis }\end{array}$ & $\begin{array}{c}\text { Pasteurellosis from } \\
\text { Pasteurella piscicida }\end{array}$ & & Furnestinia spp. & Anilocra spp. \\
\hline $\begin{array}{c}\text { Digestive larval } \\
\text { bacterlosis }\end{array}$ & $\begin{array}{c}\text { Aeromonosis from } \\
\text { Aeromonas } \\
\text { salmonicida }\end{array}$ & & Microcotyle spp. & Nerocila spp. \\
\hline
\end{tabular}

Although bacteriosis, protozoosis, and monogenosis are observed regardless of the breeding system, the parasitosis introduced by crustacean parasites are only observed in cage breeding. It should be noted that the incidence of these pathologies increases when the breeding surroundings are confined.

The estimates of yearly consumption reported here are partly based upon veterinarian prescriptions. Indeed, the complex modalities of veterinarian medicines distribution and the lack of a monitoring programme of drug prescribing preclude to give an exhaustive evaluation of drug consumption in marine fish culture. Thus, considering that the treatments are relatively uniform in the same geographic areas, we also take into account the average frequencies of treatments against the main curable diseases (Table I), currently carried out in the three major species raised in France : the sea bass (Dicentrarchus labrax), the sea bream (Sparus aurata) and the turbot (Psetta maxima). The average frequencies of treatment involve the total breeding cycle, 18-24 months for the sea bass and the sea bream, 15-18 months for the turbot. The total biomass concerned includes the three species, both the marketable fraction and the fractions in growth phase, the breeding fraction in hatcheries excluded. The corresponding standard treatment doses were chosen according to recommended doses in the literature and are figured in Table II. 
Table II

Drugs : indications and dosage in marine fish farming.

Tableau II

Indications et posologie des médicaments utilisés en pisciculture marine.

\begin{tabular}{|c|c|c|c|c|c|c|c|}
\hline $\begin{array}{l}\text { Active } \\
\text { compound }\end{array}$ & Oxyletracycline & $\begin{array}{l}\text { Sultamide + } \\
\text { Trimethoprime }\end{array}$ & $\begin{array}{l}\text { Flumequine, } \\
\text { oxolinic acid }\end{array}$ & Flortenicol & $\begin{array}{c}\text { Formol } \\
(30 \% \text { soln.) }\end{array}$ & Antiseptics & $\begin{array}{c}\text { Green } \\
\text { malachite }\end{array}$ \\
\hline Indications & Bacteria & Bacteria & Bacteria & Bacteria & Parasiles & Bacteria & Parasites \\
\hline $\begin{array}{c}\text { Orally } \\
\mathrm{mg} / \mathrm{kg} / \text { day }\end{array}$ & 80 & 40 & 15 & 15 & & & \\
\hline $\begin{array}{l}\text { Complete } \\
\text { treatment } \\
\mathrm{mg} / \mathrm{kg} / \text { week }\end{array}$ & 560 & 280 & 105 & 105 & & & \\
\hline Bathing mg / I & 20 & 20 & 20 & 20 & 300 & 20 & 0.5 \\
\hline For $10 \mathrm{~m}^{3}$ & $200 \mathrm{~g}$ & $200 \mathrm{~g}$ & $200 \mathrm{~g}$ & $200 \mathrm{~g}$ & 3 liters & $200 \mathrm{~g}$ & $5 g$ \\
\hline
\end{tabular}

Based on the indication for drug therapy, the treatment of parasitic diseases accounts for more than $70 \%$ of drug prescriptions. The yearly amount of antibacterials used in marine farmed fish reached $1500 \mathrm{~kg}$. This level is strongly influenced by oxytetracycline, still considered as a compound of primary use.

It is important to emphasize that these data, partly based on average frequencies of treatment and standard treatment doses, are not the actual prescribed doses. Transposed in France, the Norwegian surveillance programme of drug prescribing may be received as a compulsory measure, but the results achieved in Norway during the last decade must be underlined. Its primary objective was to increase the efficiency of the control of drug residues in farmed fish. Furthermore, as the database of drug use in farmed fish provides an almost complete piece of information on drug use in all fish farms in Norway (BANGEN et al., 1994), it also gives reliable information about the bacterial disease situation in the field. These data were much more reliable than the results obtained through official general disease-reporting programmes (BANGEN et al., 1996). Additionally, the joint piece of information of the prescription reporting surveillance from resistance monitoring programme initiated by the Norwegian College of Veterinary Medicine provides useful pharmaco-epidemiological information to the aquaculture industry (BANGEN et al., 1996).

The environmental requirements practiced by the fish farming industry give rise to multiple questions relative to the stable development of these productions. The environmental pressure due to the waste products of stock husbandry safety was recently studied, mainly in Northern Europe. These studies demonstrated the persistance of medicinal waste in the aquatic environment (LUNESTAD, 1991 ; SAMUELSEN et al., 1992 ; POULIQUEN et al., 1996) which induces toxic effects on the wildlife (EGIDIUS and MOSTER, 1987 ; HORSBERG et al., 1989) and changes in the bacterial communities in sediments likely to affect biological geochemical cycles (GRAY and HERWIG, 1996 ; HANSEN et al., 1992 ; WU and KNOWLES, 1995). These studies confirm that the environmental impact depends mainly on the nature, but to a lesser degree, however, on the quantity of used drugs. In the last few years, antibacterials were in sight. 


\section{Table III}

Drugs : estimated consumption in marine fish farming.

\section{Tableau III}

Estimation de la consommation en pisciculture marine.

\begin{tabular}{|c|c|c|c|c|c|}
\hline Products & Antibiotics & Formol & Green malachite & Antiseptics & $\begin{array}{c}\text { Organo- } \\
\text { phosphates }\end{array}$ \\
\hline $\begin{array}{c}\text { Biomass } \\
\text { concerned }\end{array}$ & $6000 \mathrm{t}$ & $\begin{array}{c}2000 \mathrm{t}-40 \mathrm{~kg} / \mathrm{m}^{3} \\
\text { in } 50000 \mathrm{~m}^{3}\end{array}$ & $\begin{array}{c}1000 \mathrm{t}-40 \mathrm{~kg} / \mathrm{m}^{3} \\
\text { in } 25000 \mathrm{~m}^{3}\end{array}$ & & \\
\hline Dose per treatment & $500 \mathrm{~g} / \mathrm{t}$ & $31 / 10 \mathrm{~m}^{3}$ & $5 \mathrm{~g} / 10 \mathrm{~m}^{3}$ & & \\
\hline $\begin{array}{c}\text { Average estimated } \\
\text { frequency of } \\
\text { treatment }\end{array}$ & $0.5 /$ year & $3 /$ year & $0.5 /$ year & low & negligible \\
\hline $\begin{array}{c}\text { Annual estimated } \\
\text { consumption }\end{array}$ & $1500 \mathrm{~kg}$ & $45000 \mathrm{l}$ & $6.25 \mathrm{~kg}$ & & \\
\hline
\end{tabular}

The present study shows that the annual estimated consumption of antibacterial drugs is about $250 \mathrm{mg}$ of active ingredients per $\mathrm{kg}$ of marine farmed fish. This level is close to the total volume used in Norway during the period 1980-1988 (GRAVE et al., 1996). The total volume of antibiotics currently used in France is still very close to that used in Norway in 1994 for a producted biomass 50 times more (GRAVE et al., 1996). This volume is also approximately ten times less than in the freshwater fish farm industry (PASCO, 1994). These figures should encourage the revision of priorities so that, on one hand, the principle of an equal evaluation of flux pollutants can be respected; and, on the other hand, the control of marine fish farming waste into the environment does not weigh unfairly on the development of this new industry in full expansion.

\section{REFERENCES}

BANGEN M., GRAVE K., NORDMO R., SOLI N.E., 1994. Description and evaluation of a new surveillance programme for drug use in fish farming in Norway. Aquaculture, 119, 109-118.

BANGEN M., GRAVE K., HORSBERG T.E., 1996. Surveillance of drug prescribing for farmed fish in Norway : possible applications of computerized prescription information. J. Vet. Pharmacol. Therap., 19, 78-81.

BLANC G., POULIQUEN H., LE BRIS H., 1998. La chimiothérapie en aquaculture, aspects scientifiques et juridiques du médicament vétérinaire. INRA Editions. (In press).

EGIDIUS E., MOSTER B., 1987. Effect of Neguvon and Nuvan treatment on crabs (Cancer pagurus, Carcinus maenas), lobster (Homarus gammarus) and blue mussel (Mytilus edulis). Aquaculture, 60, 165-168.

GRAVE K., MARKESTAD A., BANGEN M., 1996. Comparison in prescribing patterns of antibacterial drugs in salmonid farming in Norway during the period 1980-1988 and 1989-1994. J. Vet. Pharmacol. Therap., 19, 184-191.

GRAY J.P., HERWIG R.P., 1996. Phylogenetic analysis of the bacterial communities in marine sediments. Appl. Environ. Microbiol., 62 (11), 4049-4059.

HANSEN P.K., LUNESTAD B.T., SAMUELSEN O.B., 1992. Effects of oxytetracycline, oxolinic acid and flumequine on bacteria in an artificial marine fish farm sediment. Can. J. Microbiol., 38, 1307-1312. 
HORSBERG T.E., HOY T., NAFSTAD I., 1989. Organophosphate poisoning of Atlantic salmon in connection with treatment against salmon lice. Acta. Vet. Scand., 30, 385-390.

LUNESTAD B.T., 1991. Fate and effects of antibacterial agents in aquaculture environments. In Chemotherapy in aquaculture from theory to reality, Office International des Epizooties, 97, Paris, 12-15 mars 1992, $106 \mathrm{p}$.

PASCO L., 1994. Thérapeutique antibactérienne en pisciculture. European symposium antimicrobials in animal intensive production, CNEVA-ISPAIA Ed., Ploufragan, 25-27 October, ISPAIA, 117-121.

PILLAY T.V.R., 1997. Aquaculture and the Environment. Fishing News Books Ed., Oxford, England, $185 \mathrm{p}$.

POULIQUEN H., LE BRIS H., BUCHET V., PINAULT L., 1996. Comparative Study on the Contamination and Decontamination of Japanese Oyster Crassostrea gigas and Blue Mussel Mytilus edulis by Oxytetracycline and Oxolinic Acid. Marine ecology progess series, 133, 143-148.

SAMUELSEN O.B., TORSVIK V., ERVIK A., 1992. Long-range changes in oxytetracycline concentration and bacterial resistance towards oxytetracycline in a fish farm sediment after medication. The Science of the Total Environment, 114, 25-36.

WU Q., KNOWLES R., 1995. Effect of chloramphenicol on denitrification in Flexibacter candensis and Pseudomonas denitrificans. Appl. Env. Microbiol., 61 (2), 434-437. 